\title{
Marek Dylewski
}

\section{BUDŻET ROCZNY - NARZĘDZIE STABILIZACJI CZY DESTABILIZACJI SYSTEMU FINANSOWEGO JST}

\section{Wprowadzenie}

Od początku transformacji jednostki samorządu terytorialnego (JST) niejako już przyzwyczaiły się do instytucji budżetu. Niezmiennie od momentu reaktywacji samorządu terytorialnego w Polsce podstawą gospodarki finansowej JST jest budżet roczny. Jest to zasadniczy dokument realizacji zadań publicznych przez JST niezależnie od ich szczebla - gminy, powiatu czy też województwa samorządowego. Jednakże wiele zmieniło się od momentu ponownego zaistnienia samorządu terytorialnego w sektorze finansów publicznych w Polsce. Budżet nie jest jedynym odzwierciedleniem zasobów finansowych JST. Zadania realizowane są już nie tylko przez podmioty typowo budżetowe, ale coraz częściej mamy do czynienia $z$ innymi formami, które nie zawsze mają powiązanie $\mathrm{z}$ budżetem.

Decyzje podejmowane przez organy JST w dużej części mają charakter średnio- lub długoterminowy. Zawierane umowy na dostawy lub usługi także w coraz większym stopniu mają charakter wieloletni. Tym samym, stopniowo budżet roczny w dużej mierze traci na znaczeniu na rzecz narzędzi o charakterze długoterminowym (wieloletnim). $Z$ tego też powodu rodzi się pytanie badawcze i jednocześnie cel niniejszego artykułu, czy budżet roczny dalej powinien być podstawowym dokumentem i podstawą gospodarki finansowej JST, czy należy dokonać zmian w systemie budżetowym. Wątpliwości te wynikają z pytania badawczego, czy budżet roczny w obecnych uwarunkowaniach jest narzędziem stabilizującym, czy też destabilizującym system finansowy JST.

\footnotetext{
1 Dr hab. prof. Marek Dylewski, Instytut Finansów, Wydział Finansów i Bankowości, Wyższa Szkoła Bankowa w Poznaniu.
} 


\section{Budżet roczny w systemie finansowym JST}

Budżet zazwyczaj charakteryzuje się i definiuje w sposób opisowy poprzez wskazanie jego najistotniejszych cech. Jest to odzwierciedlenie sposobów i środków wykorzystywanych do osiągnięcia zakładanych celów poprzez wpływ i oddziaływanie na zachowania społeczeństwa ${ }^{2}$. Budżet jest scentralizowanym funduszem publicznym służącym do gromadzenia środków pieniężnych. W wąskim ujęciu można scharakteryzować go jako zbiór tych cech, które najlepiej oddają jego istotę:

1) budżet jest funduszem scentralizowanych zasobów pieniężnych gromadzonych i dzielonych przez JST w związku z realizacją zadań (funkcji) publicznych;

2) budżet jako fundusz musi cechować specjalizacja, polegająca na nadawaniu rygorów prawnych wydatkom budżetowym;

3) gromadzenie środków budżetowych odbywa się - z reguły - w sposób przymusowy i stanowi atrybut władzy samorządowej;

4) budżet pełni istotne funkcje społeczne i gospodarcze (w szczególności stabilizując i stymulując gospodarkę, alokując fundusze publiczne);

5) procesy gromadzenia i rozdysponowania przez JST dochodów w budżecie zawsze mają charakter nie tylko ekonomiczny, lecz także społeczny; wyraża się to w przejmowaniu (redystrybucji) części produktu społecznego i dysponowania nim, co wpływa na sytuację dochodową i socjalną poszczególnych osób, grup społecznych;

6) procesy gromadzenia dochodów i ich rozdysponowywania za pomocą instytucji budżetu implikują zasady ustrojowo-konstytucyjne;

7) budżet dotyczy działalności organów i podmiotów podsektora samorządowego (stanowiącego część sektora publicznego) w przyszłości, stąd też jest zawsze planem dochodów i wydatków oraz przychodów i rozchodów na z góry ustalony czas;

8) strumieniowy charakter budżetu oznacza konieczność egzekwowania należnych w danym okresie dochodów, jak również obliguje do wydatkowania środków budżetowych przed upływem okresu budżetowego;

9) budżet nie jest jedynym dokumentem/narzędziem, w którym znajduje odzwierciedlenie działalność sektora publicznego, a w szczególności samorządowego, co oznacza, że nie może on być wystarczającą podstawą do dokonywania jego oceny.

2 R.C. Fisher, State and Local Public Finance, Scott, Foresman and Company, Glenview 1987, s. 425.

3 Por. S. Owsiak, Finanse publiczne. Teoria i praktyka, Wydawnictwo Naukowe PWN, Warszawa 2005, s. 115-116; M. Dylewski, Planowanie budżetowe w podsektorze samorzadowym. Uwarunkowania, procedury, modele, Difin, Warszawa 2007, s. 95-96; Planowanie budżetowe a alokacja zasobów, red. S. Owsiak, PWE, Warszawa 2008, s. 22-23. 
Z przedstawionych wyżej cech wyraźnie widać, że budżet jest podstawowym planem finansowym obejmującym zestawienie przewidywanych dochodów i wydatków państwa lub JST, ujętych w odpowiednim stopniu szczegółowości i w określonym przedziale czasowym, zwykle, a w uwarunkowaniach polskich wyłącznie w okresie roku. Praktyka pokazuje jednak, że okres jednoroczności w przypadku realizowania zadań średnio- i długoterminowych, a także zadań inwestycyjnych niesie za sobą duże prawdopodobieństwo nieefektywnego zastosowania zasobów publicznych oraz błędnych ocen podejmowanych decyzji, które skutkują (często w sposób negatywny) na okresy przyszłe ${ }^{4}$.

Budżet i procesy budżetowe to nie tylko przygotowanie dokumentu pod względem legalnym. Proces planowania budżetu uwzględnia wymiary polityczny, zarządczy, planistyczny, komunikacyjny i finansowy. Zgodnie z rekomendacjami Government Finance Officers Association dobry budżet powinien uwzględniać perspektywę długoterminową, powiązania z ogólnymi celami organizacyjnymi, skupiać decyzje budżetowe na wynikach i efektach, sprzyjać efektywnej komunikacji z interesariuszami oraz pracownikami ${ }^{5}$.

Na podkreślenie zasługuje ostatni element $\mathrm{z}$ cech budżetu, który wyraźnie wskazuje, że działalność sektora publicznego nie jest odzwierciedlona tylko w budżecie. W oparciu o to można wyodrębnić podmiotowy układ realizacji zadań publicznych w JST, który obrazuje także tę część zadań, która jest realizowana przez podmioty niepowiązane $\mathrm{z}$ budżetem JST:

1) zadania realizowane przez jednostki budżetowe i samorządowe zakłady budżetowe, czyli jednostki bezpośrednio lub pośrednio powiązane z budżetem (metodą brutto lub netto);

2) zadania realizowane przez samorządowe osoby prawne, nad którymi JST posiada nadzór, ale nie są one powiązane bezpośrednio z budżetem, choć mogą być w części finansowane ze środków budżetowych (jednostki kultury, samodzielne publiczne zakłady opieki zdrowotnej itp.);

3) zadania realizowane przez spółki prawa handlowego, w których dominującym (lub też nie) udziałowcem są JST;

4) inne formy realizacji zadań publicznych, takie jak partnerstwo publiczno-prywatne, które obejmuje łączne zaangażowanie partnera publicznego i prywatnego.

4 Zob. także M. Poniatowicz, J.M. Salachna, D. Perło, Efektywne zarządzanie długiem w jednostce samorządu terytorialnego, Wolters Kluwer Polska, Warszawa 2010, s. 161-164.

5 Recommended Budget Practices: A Framework For Improved Stateand Local Government Budgeting, National Advisory Council on State and Local Budgeting Government Finance Officers Association, Chicago 1999. 
Doświadczenia ostatnich lat oraz likwidacja niektórych form gospodarki budżetowej ${ }^{6}$ wskazują, że wzrasta znaczenie realizacji zadań publicznych w oparciu o spółki prawa handlowego. Dotyczy to jednak tych usług, które mogą mieć charakter pełnej lub częściowej odpłatności .

Trzecia ustawa o finansach publicznych określiła budżet JST jako roczny plan dochodów i wydatków oraz przychodów i rozchodów tej jednostki, uchwalany na rok budżetowy, przy czym rokiem budżetowym jest rok kalendarzowy. Podstawą gospodarki finansowej JST w danym roku budżetowym jest uchwała budżetowa, która składa się z budżetu JST i załączników ${ }^{8}$. Należy podkreślić, że mówiąc o gospodarce finansowej JST, należy ją rozumieć w ujęciu wąskim, ograniczonej do procesów gromadzenia dochodów budżetowych i realizacji wydatków budżetu. Nie dotyczy to szerokiej sfery pozabudżetowej. W ujęciu formalnoprawnym uchwała budżetowa (zawierająca budżet JST) określa9:

1) łączną kwotę planowanych dochodów budżetu JST, z wyodrębnieniem dochodów bieżących i majątkowych;

2) łączną kwotę planowanych wydatków budżetu JST, z wyodrębnieniem wydatków bieżących i majątkowych;

3) kwotę planowanego deficytu albo planowanej nadwyżki JST wraz ze źródłami pokrycia deficytu albo przeznaczenia nadwyżki budżetu JST;

4) łączną kwotę planowanych przychodów i rozchodów budżetu JST;

5) limit zobowiązań z tytułu zaciąganych kredytów i pożyczek oraz emitowanych papierów wartościowych;

6) kwotę wydatków przypadających do spłaty w danym roku budżetowym, zgodnie z zawartą umową, z tytułu poręczeń i gwarancji udzielonych przez JST;

7) szczególne zasady wykonywania budżetu JST w roku budżetowym, wynikające z odrębnych ustaw;

8) uprawnienia jednostki pomocniczej do prowadzenia gospodarki finansowej w ramach budżetu gminy;

9) inne postanowienia, których obowiązek zamieszczenia w uchwale budżetowej wynika z postanowień organu stanowiącego JST.

6 Dotyczy to likwidacji gospodarstw pomocniczych jednostek budżetowych oraz ograniczenia katalogu usług, które mogą być realizowane przez samorządowe zakłady budżetowe.

7 Szerzej na temat przekształceń w zakresie realizacji zadań publicznych w: M. Dylewski, Procesy zmian $w$ zarzadzaniu gospodarką komunalna w jednostkach samorzadu terytorialnego na tle uwarunkowań legislacyjnych, „Nauki o finansach. Financial Sciences”, Wydawnictwo Uniwersytetu Ekonomicznego we Wrocławiu, 2013, 4(17), s. 11-21.

8 Ustawa z dnia 27 sierpnia 2009 r. o finansach publicznych, DzU nr 157, poz. 1240 ze zm., art. 211.

9 Ibidem, art. 212. 
Biorąc pod uwagę układ budżetu, jego zawartość, rolę oraz wyzwania związane ze stabilizowaniem finansów samorządowych:

- instytucja budżetu JST jest ograniczona do katalogu dochodów i wydatków, które wynikają z realizowanych przez JST zadań i z ustawy o finansach publicznych oraz ustaw szczegółowych regulujących sposób realizacji poszczególnych zadań publicznych, a tym samym budżet roczny nie zawiera informacji o realizacji zadań wykraczających poza rok budżetowy;

- budżet JST nie zawiera informacji o angażowaniu pozabudżetowych zasobów JST, co ma szczególne znaczenie dla stabilności sytemu finansowego JST;

- istnieją ograniczone możliwości wykorzystania budżetu rocznego jako narzędzia zarządczego w procesie podejmowania decyzji organów JST, których skutki wykraczają poza okres jednego roku ${ }^{10}$.

Z przedstawionych rozważań wynika, że budżet JST jest jednym $\mathrm{z}$ wielu elementów składających się na zasoby systemu finansowego JST. Zasobami finansowymi będą wszystkie te wpływy (środki), które są angażowane w realizację przez JST zadań publicznych. W układzie podmiotowo-przedmiotowym schemat systemu finansowego JST zaprezentowano na rysunku 1.

Rysunek 1. System finansowy JST w ujęciu podmiotowym

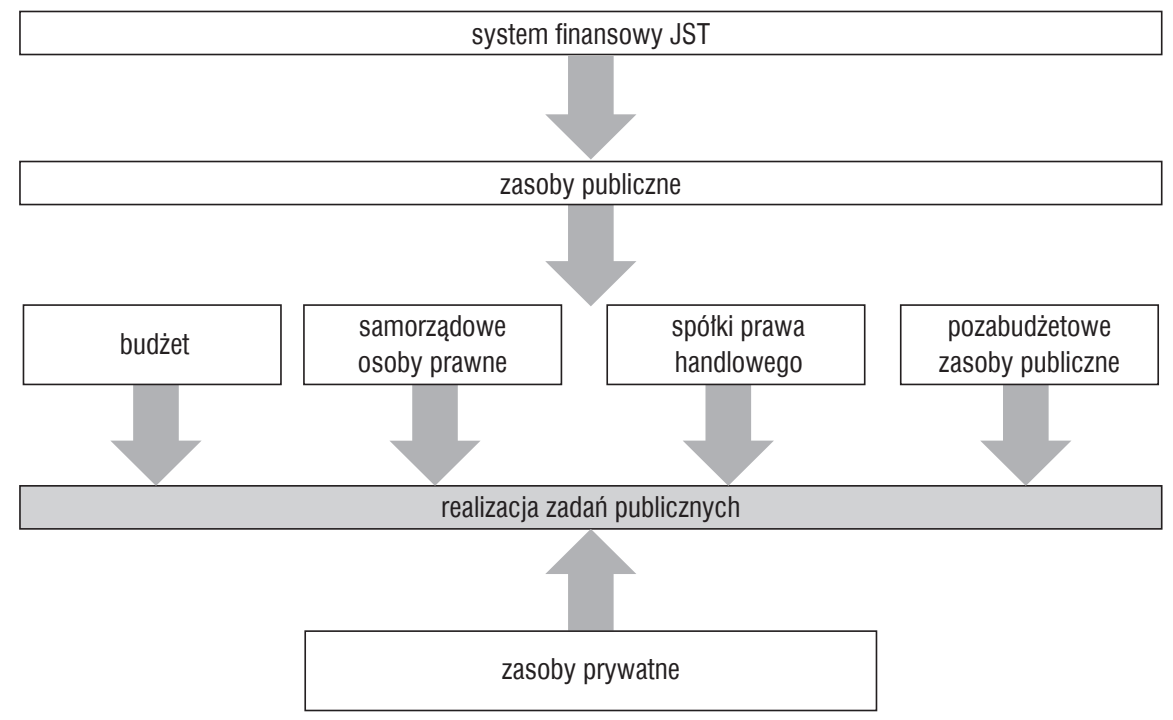

Źródło: Opracowanie własne.

$10 \mathrm{Na}$ ten element wskazuje B. Filipiak w: Finanse samorządowe. Nowe wyzwania bieżace i perspektywiczne, Difin, Warszawa 2011, s. 55. 
Zasoby finansowe JST mogą być angażowane rozłącznie lub poprzez różne montaże finansowe angażujące podmiotowo różne strumienie finansowe. Poziom komplikacji sektora finansów publicznych w Polsce oraz brak skonsolidowanego podejścia do zasobów finansowych JST powoduje, że realizowane przez nie zadania mogą być finansowane $\mathrm{z}$ różnych strumieni finansowych, przy czym należy podkreślić, że nie zawsze możliwe jest skonsolidowane podejście do angażowania środków JST w realizację zadań publicznych z powodów czysto formalnoprawnych. Nie sprzyja to efektywnej realizacji zadań publicznych. W tabeli 1 zaprezentowano skonsolidowane ujęcie przychodów JST, ale tylko w części obejmującej jednostki i zakłady budżetowe i jako takie podlega prezentacji i jest analizowane w zakresie dotyczącym absolutorium dla organu wykonawczego.

Tabela 1. Przychody wybranych JST w ujęciu skonsolidowanym - budżetowym

\begin{tabular}{|l|c|c|c|c|}
\hline \multicolumn{1}{|c|}{ Wyszczególnienie } & Poznań & Warszawa & Gdańsk & Szczecin \\
\hline Przychody ogótem & 3421562334 & 13246537756 & 2762581235 & 2053517376 \\
\hline Dochody budżetu & 3178764042 & 10804735692 & 2619293934 & 1992074909 \\
\hline Zasoby pozabudżetowe & 242798291 & 2441802064 & 143287302 & 61442467 \\
\hline $\begin{array}{l}\text { Relacja zasobów pozabudżetowych } \\
\text { do dochodów budżetu (w \%) }\end{array}$ & 7,6 & 22,6 & 5,5 & 3,1 \\
\hline
\end{tabular}

Źródło: Opracowanie własne na podstawie biuletynów informacji publicznej.

Jak widać $\mathrm{z}$ danych zaprezentowanych $\mathrm{w}$ tabeli 1, wielkość przychodów, poza stricte budżetowymi, nie jest znacząca, z wyjątkiem miasta stołecznego Warszawa. Należy jednak podkreślić, że brak w tym ujęciu przychodów pozostałych jednostek, takich jak instytucje kultury (jako osoby prawne), samodzielne publiczne zakłady opieki zdrowotnej, spółki prawa handlowego. Wskazuje to na bardzo ograniczone ujęcie zasobów finansowych JST. Skonsolidowane pełne sprawozdania nie są w obecnym systemie prawnym wykorzystywane w procesie podejmowania decyzji przez organy JST.

\section{Warunki stabilności systemu finansowego JST - budżet roczny a planowanie wieloletnie}

Wprowadzając nową ustawę o finansach publicznych w 2009 r., dodano nowy instrument planistyczny, jakim jest wieloletnia prognoza finansowa (WPF) JST. Do tej pory obowiązkowym dokumentem wieloletnim była tylko prognoza długu publicznego. Należy podkreślić, że jest to całkowicie odrębny od budżetu dokument, który 
podlega specyficznym wymogom ustawowym. W odniesieniu do JST WPF ma ona pełnić taką rolę jak wieloletni plan finansowy państwa ${ }^{11}$. Można powiedzieć, że WPF jest prognozą budżetu w ujęciu wieloletnim ${ }^{12}$, uzupełnioną o prognozy finansowe w zakresie wieloletnich programów współfinansowanych ze środków zagranicznych, skutki finansowe wynikające z zawartych umów o partnerstwie publiczno-prywatnym oraz inne wieloletnie umowy, programy finansowe, poręczenia i gwarancje ${ }^{13}$. WPF ma charakter „kroczący”, a jej zakres czasowy jest co roku przedłużany. Należy przy tym dodać, że WPF nie jest dokumentem obowiązkowym i jeśli dana JST nie jest zadłużona oraz nie realizuje zadań wieloletnich, to nie jest zobowiązana do sporządzania i uchwalania WPF (co w praktyce raczej jest zjawiskiem niewystępującym).

Zakres merytoryczny WPF został określony w ustawie o finansach publicznych. WPF w swym zakresie powinien zawierać dla każdego roku objętego prognozą co najmniej ${ }^{14}$ :

- dochody bieżące oraz wydatki bieżące budżetu JST, w tym na obsługę długu, gwarancje i poręczenia;

- dochody majątkowe, w tym dochody ze sprzedaży majątku, oraz wydatki majątkowe;

- wynik budżetu JST;

- przeznaczenie nadwyżki albo sposób sfinansowania deficytu;

- przychody i rozchody budżetu JST, z uwzględnieniem długu zaciągniętego oraz planowanego do zaciągnięcia;

- kwoty wydatków bieżących i majątkowych wynikających z limitów wydatków na planowane i realizowane przedsięwzięcia;

- objaśnienia przyjętych wartości.

Należy podkreślić, że największą komplikację w wykorzystaniu tego narzędzia powoduje zapis ustawy, który określa konieczność ujęcia w planie wydatków kwoty wydatków bieżących i majątkowych wynikających z limitów wydatków na planowane i realizowane przedsięwzięcia, kwoty wydatków na wynagrodzenia i składki od nich naliczane oraz wydatki związane z funkcjonowaniem organów JST. Z pragmatycznego punktu widzenia takie uszczegółowienie nie do końca jest uzasadnione (szczególnie w zakresie wynagrodzeń i wydatków związanych z funkcjonowaniem organów JST), skoro i tak w budżecie rocznym wskazane wielkości są wyodrębniane i w sposób zależny od organu wykonawczego i stanowiącego ustalane.

\footnotetext{
11 L. Patrzałek, Finanse samorządu terytorialnego, Wydawnictwo UE we Wrocławiu, Wrocław 2010, s. 120.

12 Ustawa z dnia 27 sierpnia 2009 r. o finansach publicznych, op.cit., art. 226.

13 C. Kosikowski, Naprawa finansów publicznych w Polsce, Temida, Białystok 2011, s. 482; M. Poniatowicz, Wpływ kryzysu gospodarczego na systemy finansowe jednostek samorzadu terytorialnego. Na przykładzie największych miast w Polsce, CeDeWu, Warszawa 2014, s. 165-166.

14 Ustawa z dnia 27 sierpnia 2009 r. o finansach publicznych, op.cit., art. 226.
} 
Jest to jednak problematyczne, gdy JST funkcjonuje w oparciu o budżet roczny $\mathrm{w}$ ujęciu tradycyjnym. WPF wymusza obowiązek uwzględnienia przedsięwzięć, których zakres został stosunkowo precyzyjnie określony. Oznacza to konieczność wyodrębnienia każdego planowanego do realizacji przedsięwzięcia (czyli wieloletnich programów, projektów lub zadań) ${ }^{15}$. Dodatkowo WPF nie jest dowolnie kształtowanym dokumentem. Minister finansów w sposób szczegółowy określił jego wzór wsparty aplikacją informatyczną, co oznacza, że w efekcie końcowym dokument ten służy bardziej stronie rządowej niż samorządowej ${ }^{16}$. W efekcie końcowym skupiono się na elementach ładu prawnego w zakresie funkcjonowania WPF, co pomija w zupełności możliwości wykorzystania WPF jako narzędzia zarządczego. Nie bierze się w tym przypadku pod uwagę uzasadnionych potrzeb informacyjnych zarządzających finansami JST.

Istotnym pytaniem jest zakres zgodności budżetu rocznego JST z zapisami WPF. Innymi słowy, jest to pytanie o hierarchię i rangę obu dokumentów, stopień ich wzajemnej spójności oraz implikacje wynikające z procesów planistycznych i legislacyjnych w JST. Wartości przyjęte w WPF i budżecie JST powinny być zgodne tylko w zakresie wyniku budżetu (nadwyżka/deficyt/równowaga) i związanych z nim kwot przychodów i rozchodów oraz długu JST. Oznacza to, że mogą występować duże rozbieżności co do zawartości budżetu danego roku i zapisów WPF. Tym samym istota wykorzystania obu narzędzi do stabilizacji systemu finansowego JST zaciera się. W tabeli 2 zaprezentowano porównanie stopnia zgodności budżetu rocznego i WPF.

Przyjęcie budżetu rocznego, jako planu dochodów i wydatków budżetowych oraz przychodów i rozchodów, o ile realne są zapisy w nim zawarte, w zasadzie można powiedzieć, że kończy problematykę procesu planowania, ponieważ przez okres najbliższego roku mamy do czynienia z etapem wykonawczym tych zadań, które zostały zapisane w budżecie i ewentualnymi korektami planu w zależności od tego, jak przebiega proces wykonywania budżetu. Jednocześnie wcale nie musi być on zgodny w zakresie realizowanych zadań z WPF. W warunkach regulacji prawnych w Polsce tak przyjęty model planowania zadań publicznych - w zasadzie niespójny - może prowadzić w skrajnych przypadkach do destabilizacji systemu finansowego JST. W szczególności przy zmianach rządzących daną JST takie sytuacje nie są wykluczone. Jednakże największym elementem destabilizującym system finansowy JST jest brak hierarchii i wskazania, który z dokumentów powinien być wiodący. Rozwiązania

15 B. Filipiak, Finanse samorzadowe..., op.cit., s. 68.

16 Rozporządzenie Ministra Finansów z dnia 10 stycznia 2013 r. w sprawie wieloletniej prognozy finansowej jednostki samorządu terytorialnego, DzU 2013, poz. 86 ze zm. 
w innych krajach wyraźnie wskazują, że plan o charakterze długoterminowym jest nadrzędny $\mathrm{w}$ stosunku do krótkoterminowego (operacyjnego), który jest $\mathrm{w}$ takim przypadku narzędziem realizacji zawartych w planie długoterminowym zadań ${ }^{17}$.

Tabela 2. Budżet roczny a WPF

\begin{tabular}{|c|c|c|}
\hline & Budżet roczny & WPF \\
\hline $\begin{array}{l}\text { Stopień zgodności } \\
\text { dokumentów }\end{array}$ & $\begin{array}{l}\text { - charakter nadrzędny budżetu rocznego nad } \\
\text { WPF } \\
\text { - zapisy budżetu rocznego są podstawą } \\
\text { konstrukcji WPF jako aktu prawnego }\end{array}$ & $\begin{array}{l}\text { - brak cechy uprzedniości w zakresie } \\
\text { wielkości ujmowanych w WPF } \\
\text { - WPF nie jest dokumentem nadrzędnym dla } \\
\text { budżetu rocznego } \\
\text { - wymagana zgodność z budżetem } \\
\text { rocznym co do wyniku budżetu, wielkości } \\
\text { przychodów i rozchodów, poziomu długu }\end{array}$ \\
\hline $\begin{array}{l}\text { Procedura } \\
\text { legislacyjna }\end{array}$ & \multicolumn{2}{|c|}{$\begin{array}{l}\text { - brak hierarchii pomiędzy budżetem rocznym a WPF } \\
\text { - przyjęte zapisy WPF nie są obligatoryjnym zobowiązaniem do zawarcia ich w budżecie } \\
\text { - docznym }\end{array}$} \\
\hline Ciągłość planowania & $\begin{array}{l}\text { - każdy budżet roczny jest odrębnym } \\
\text { dokumentem } \\
\text { - nie jest wymagane zachowanie ciągłości } \\
\text { planowania (kontynuacji zadań) }\end{array}$ & $\begin{array}{l}\text { - zachowana, ale tylko w obszarze } \\
\text { dokumentu, jakim jest WPF } \\
\text { - brak automatyzmu w zakresie zmian budżetu } \\
\text { rocznego wynikającego z zapisów lub ze } \\
\text { zmiany WPF }\end{array}$ \\
\hline $\begin{array}{l}\text { Poziom formalizacji } \\
\text { procesu } \\
\text { przygotowania } \\
\text { i uchwalania } \\
\text { dokumentu }\end{array}$ & $\begin{array}{l}\text { - ścisły podział kompetencji pomiędzy organ } \\
\text { stanowiący i wykonawczy } \\
\text { - precyzyjny harmonogram czasowy } \\
\text { w zakresie procesu uchwalania budżetu } \\
\text { wraz z działaniami w przypadku jego } \\
\text { nieuchwalenia }\end{array}$ & $\begin{array}{l}\text { - formalizm ograniczony tylko do zawartości } \\
\text { merytorycznej i szczątkowej zgodności } \\
\text { z budżetem JST }\end{array}$ \\
\hline
\end{tabular}

Źródło: Opracowanie własne.

Doświadczenia innych krajów pokazują, że proces planowania może być jednolitym i wewnętrznie spójnym narzędziem zachowującym swoją hierarchiczność podporządkowaną procesowi zarządzania zarówno w ujęciu krótko-, jak i długoterminowym. WPF jest sporządzany zgodnie z określoną szczegółowością. Problem stanowi fakt, że jest ona mniejsza niż zakres informacyjny niezbędny do podejmowania decyzji przez organy JST. Ponadto od uznania tak naprawdę w praktyce sporządzających WPF pozostaje kwestia objaśnień wartości przyjętych w WPF. W związku z powyższym można się spodziewać różnych rozwiązań w tym zakresie (od syntetycznych wskazówek po obszerne opracowania wyjaśniające zasady konstrukcji). Tym samym organy JST tracą możliwość podjęcia optymalnej decyzji, gdyż nie wiedzą, jakie założenia szczegółowe mogły być przyjęte oraz czy są one porównywalne z okresami wcześniejszymi. Przy minimalnej zawartości WPF problem sprowadza się

17 Szerzej o rozwiązaniach w takich krajach jak USA, Australii i Nowa Zelandia w: Budżet zadaniowy metoda racjonalizacji wydatków, red. B. Woźniak, M. Postuła, CeDeWu, Warszawa 2012, s. 209-220. 
do uzyskania zgodności w zakresie parametrów zawartych w art. 243 ustawy o finansach publicznych przynajmniej w trzech kolejnych latach, ponieważ jest to warunek uchwalenia budżetu na dany rok budżetowy ${ }^{18}$. Tym samym uchwalenie budżetu na dany rok budżetowy uzależnione jest od spełnienia wymogów w zakresie IWZ, który to jest determinowany wykonaniem poprzednich trzech lat budżetowych. "Manewry” dostosowawcze często nie mają nic wspólnego z realnym planowaniem wieloletnim, na które wskazuje art. 226 ust. 1 ustawy o finansach publicznych, ponieważ IWZ ma swoje istotne wady i fundamentalne błędy, co powoduje, że nie przystaje do warunków aktywnego zarządzania finansami i realizacji polityki stabilizacji finansowej JST ${ }^{19}$. Taki sposób podejścia odwraca klasyczny układ podejścia do procesu planowania - w pierwszej kolejności cele długoterminowe i plan wieloletni, który powinien być podstawą konstrukcji budżetu rocznego. W warunkach obowiązywania zapisów art. 243 ustawy o finansach publicznych warunkiem uchwalenia budżetu jest taka konstrukcja WPF, aby zachować warunki graniczne określone w IWZ. Prezentowane podejście prawne jest zupełnie odwrotne niż klasyczne i merytorycznie zasadne podejście do procesów planistycznych. Jest to bodaj chyba najważniejsza przyczyna i zagrożenie destabilizacji finansowej JST w latach przyszłych.

Prawidłowe podejście w zakresie metodyki tworzenia WPF powinno uwzględniać opis przyjętych założeń w procesie prognozowania, uwzględnienie występujących tendencji, przyjęcie odpowiedniej metody symulacji wraz z założeniami. Brak odniesienia się do wskazanych kwestii metodycznych ograniczy wartość poznawczą, ale również wiarygodność sporządzonej prognozy. Konieczne jest również przygotowanie analizy wrażliwości kształtowania się poszczególnych wielkości wyjściowych przyjętych do prognozowania. Bardzo często zaleca się wykorzystanie strestestów w prognozowaniu takich wielkości, jak dochody, wydatki czy poziom zadłużenia oraz obsługa długu.

Można zidentyfikować trzy podejścia w zakresie przyjęcia odpowiedniej kolejności priorytetów w procedurze planistycznej:

1) pierwsze podejście oparte jest na koncepcji new public management i wytycznych good governance; metodyka opracowania prognozy powinna rozpocząć się od oszacowania potrzeb wyrażających się wydatkami (kosztami realizacji zadań), do których należy dostosować możliwości finansowe i możliwości pozyskania zwrotnych środków oraz ograniczenia związane z tzw. regułami zadłużania; podejście to jest determinowane koniecznością rozważenia celowości podejmo-

18 Relacja zawarta $\mathrm{w}$ art. $243 \mathrm{w}$ zakresie limitacji zadłużenia JST w praktyce oraz w literaturze przedmiotu zwana indywidualnym wskaźnikiem zadłużenia (IWZ).

19 Szerzej o wadach IWZ i propozycjach jego korekty: K. Marchewka-Bartkowiak, M. Wiśniewski, Indywidualny wskaźnik zadłużenia JST - ocena krytyczna i propozycje zmian, „Analizy BAS” 2012, nr 21(88). 
wanych przez JST poszczególnych przedsięwzięć z punktu widzenia ich potencjalnych rezultatów i skutków finansowych, które w przyszłości mogą rodzićco; 2) zgodnie z drugim podejściem podstawą są informacje, ile i z jakich źródeł JST może pozyskać środki finansowe, a dopiero w dalszej kolejności należy prognozować wydatki budżetowe ${ }^{21}$;

3) trzecie podejście podporządkowane jest wymogom w zakresie IWZ; w takim przypadku albo eliminuje się określone wydatki uprzednio, planując budżet danego roku i w latach następnych, albo, pozostawiając określone zadania, dostosowuje się zapisy lat następnych w celu zapewnienia zgodności w zakresie IWZ22. Jak widać z przedstawionych rozważań, trudno mówić o budżecie rocznym jako narzędziu realizacji zadań publicznych zapewniającym stabilność finansową JST zarówno w okresie krótko-, jak i długoterminowym. Ze względu na luźne powiązanie budżetu rocznego z WPF nadal jest to podstawowe narzędzie realizacji zadań publicznych, a WPF przede wszystkim narzędzie kontrolne w zakresie limitacji zadłużenia.

Analiza stanu prawnego w zakresie umiejscowienia budżetu rocznego oraz WPF w systemie finansowym JST wskazuje, że budżet roczny nadal jest podstawowym dokumentem i narzędziem planowania oraz realizacji zadań publicznych w JST. Rozłączne potraktowanie obu dokumentów (uchwały budżetowej i uchwały w zakresie WPF) powoduje, że istnieje zagrożenie dużych rozbieżności pomiędzy zapisami budżetu rocznego i WPF. W klasycznym układzie planowania zadań publicznych zapisy planu wieloletniego powinny być obligatoryjną podstawą wręcz automatycznego tworzenia budżetu rocznego, jako operacyjnego wykonania zapisów, celów i przedsięwzięć w nim zawartych. W warunkach formalnoprawnych w Polsce chyba jeszcze długo nie będzie to możliwe, ponieważ zwykle postulaty strony samorządowej nie zawsze są brane pod uwagę, pomimo stosowania uzasadnionych argumentów w tym zakresie.

20 B. Filipiak, Zarzqdzanie finansami jako podstawa gospodarki finansowej w świetle Nowego Zarzadzania Publicznego (NPM), w: Kierunki modernizacji zarządzania w jednostkach samorzadu terytorialnego, red. T. Lubińska, Difin, Warszawa 2011, s. 138-145.

21 Wieloletnia prognoza finansowa jednostki samorządu terytorialnego - metodyka opracowania, Ministerstwo Finansów, Warszawa 2010, s. 11.

22 Praktyka coraz częściej widoczna w JST, w których zaczynają występować problemy z zadłużeniem i zachwiana jest długoterminowa stabilność finansowa. 


\section{Podsumowanie}

Budżet roczny nie w pełni można uznać za narzędzie stabilizacji systemu finansowego JST. Mimo ważnej roli, która pozwala na ujęcie strumieni środków finansowych, trudno mówić o możliwościach ujęcia w pełni realizowanych zadań. Aby budżet roczny mógł bez zastrzeżeń pełnić funkcję narzędzia stabilizującego, wymagane jest uwzględnienie realnie realizowanych zadań (nie tylko planowanych), nawet tych, które wykraczają poza okres roczny, powinien pozwalać na realne gospodarowanie zasobami finansowym (zarówno tymi znajdującymi się w dyspozycji JST, jak i poza jej systemem finansowym). Ponadto budżet roczny, realizując zapisy art. 242 i 243 ustawy o finansach publicznych, pozwala jedynie na ujmowanie ograniczeń dotyczących limitacji zadłużenia. Nie wspiera to możliwości, jakie daje wykorzystanie długu jako instrumentu stabilizującego finanse samorządowe.

Poważnym mankamentem budżetu jako narzędzia stabilizacji systemu finansowego jest brak powiązania części zadań, które są realizowane przez podmioty niepowiązane z budżetem JST. Tę uwagę należy również odnieść do WPF jako instrumentu, który powinien wspierać budżet w realizacji funkcji stabilizacji systemu finansowego.

Problematyczna jest również rola WPF jako narzędzia zintegrowanego z budżetem rocznym. Mimo pozytywnej oceny samej idei wykorzystania WPF jako narzędzia pozwalającego wyeliminować brak wieloletniego ujęcia przedsięwzięć i strumieni finansowych (planowanych zasileń mających służyć realizacji zadań), ocena końcowa jest negatywna. WPF posiada wiele wad, które uniemożliwiają wykorzystanie tego narzędzia jako istotnego $\mathrm{w}$ działaniach stabilizacyjnych. Idea jest słuszna, jednakże podstawową wadę należy upatrywać w podejściu planistycznym i w sztywnym podejściu do powiązania WPF z IWZ (które też wykazuje ułomność co do swojej konstrukcji).

Reasumując, należy jednoznacznie wskazać, że budżet roczny nie umożliwia stabilizacji systemu finansowego JST, porządkuje go, a nawet czasem poprzez wszystkie regulacje ustawowe destabilizuje ten system, gdyż nie zapewnia logiki planowania, która sprzyjałaby sprawnej i konsekwentnej realizacji planu, jakim jest budżet. 


\section{Bibliografia}

A Framework For Improved State and Local Government Budgeting, National Advisory Council on State and Local Budgeting Government Finance Officers Association, Chicago 1999.

Budżet zadaniowy metodą racjonalizacji wydatków, red. B. Woźniak, M. Postuła, CeDeWu, Warszawa 2012.

Dylewski M., Planowanie budżetowe w podsektorze samorzadowym. Uwarunkowania, procedury, modele, Difin, Warszawa 2007.

Dylewski M., Procesy zmian w zarzadzaniu gospodarka komunalna w jednostkach samorzadu terytorialnego na tle uwarunkowań legislacyjnych, „Nauki o finansach. Financial Sciences", Wydawnictwo UE we Wrocławiu, 2013, 4(17).

Filipiak B., Finanse samorzadowe. Nowe wyzwania bieżace i perspektywiczne, Difin, Warszawa 2011.

Filipiak B., Zarządzanie finansami jako podstawa gospodarki finansowej w świetle Nowego Zarzadzania Publicznego (NPM), w: Kierunki modernizacji zarzadzania w jednostkach samorzadu terytorialnego, red. T. Lubińska, Difin, Warszawa 2011.

Fisher R.C., State and Local Public Finance, Scott, Foresman and Company, Glenview 1987.

Kosikowski C., Naprawa finansów publicznych w Polsce, Temida, Białystok 2011.

Marchewka-Bartkowiak K., Wiśniewski M., Indywidualny wskaźnik zadłużenia JST - ocena krytyczna i propozycje zmian, „Analizy BAS” 2012, nr 21(88).

Owsiak S., Finanse publiczne. Teoria i praktyka, Wydawnictwo Naukowe PWN, Warszawa 2005.

Patrzałek L., Finanse samorządu terytorialnego, Wydawnictwo UE we Wrocławiu, Wrocław 2010.

Planowanie budżetowe a alokacja zasobów, red. S. Owsiak, PWE, Warszawa 2008.

Poniatowicz M., Wplyw kryzysu gospodarczego na systemy finansowe jednostek samorzadu terytorialnego. Na przykładzie największych miast w Polsce, CeDeWu, Warszawa 2014.

Poniatowicz M., Salachna J.M., Perło D., Efektywne zarzadzanie dlugiem w jednostce samorzadu terytorialnego, Wolters Kluwer Polska, Warszawa 2010.

Rozporządzenie Ministra Finansów z dnia 2 marca 2010 r. w sprawie szczegółowej klasyfikacji dochodów, wydatków, przychodów i rozchodów oraz środków pochodzących ze źródeł zagranicznych, DzU nr 38, poz. 207 ze zm.

Rozporządzenie Ministra Finansów z dnia 10 stycznia 2013 r. w sprawie wieloletniej prognozy finansowej jednostki samorządu terytorialnego, DzU 2013, poz. 86 ze zm.

Ustawa z dnia 27 sierpnia 2009 r. o finansach publicznych, DzU nr 157, poz. 1240 ze zm.

Wieloletnia prognoza finansowa jednostki samorzadu terytorialnego - metodyka opracowania, Ministerstwo Finansów, Warszawa 2010. 


\section{Annual budget: a tool of stabilization of local government financial system?}

The objective of this study is to answer the question should the annual budget continue to be the basic document and the basis for the financial management of local governments, or is it necessary to make changes in the budget system. These doubts arise from the research question: whether the referred annual budget in the current conditions is a tool of stabilization of the financial system of local government units or not? Introduced in the Public Finance Act of 2009, the system of two independent documents, i.a. the annual budget and the long-term financial forecast, without specification of hierarchy, relationship and connection between these documents, does not lead to financial stability of local government from both the point of view of implementation of the budget and the consequences of decisions made by the local government authorities. The lessons that have been learned indicate that the annual budgeting is increasingly leading to destabilization of the financial system of local government units.

Keywords: annual budget, the long-term financial forecast in local government, financial system, stabilization tools

\section{Budget annuel - un outil de stabilisation ou de déstabilisation du système financier des EAL}

Lobjectif de la recherche et sa question principale est si le budget annuel doit toujours être considéré comme le document de référence et la base financière des EAL ou, au contraire, il serait nécessaire d'introduire des changements dans le système budgétaire. Ces doutes résultent de l'objet-même de la recherche portant sur le budget en question et son rôle en tant qu'agent stabilisant ou déstabilisant le système financier des EAL. Le système des deux documents indépendants, adopté dans la loi sur les finances publiques en 2009, notamment le budget annuel et les prévisions financières pluriannuelles, où ni leur hierarchie ni liens réciproques précis ne sont définis, ne peut être vu comme solution favorisant la stabilité financière des EAL en ce qui concerne la réalisation du budget, ainsi que les résultats des décisions entreprises par les EAL. La recherche et les analyses des matériaux collectés ont été réalisées à l'aide de la littérature et des actes législatifs en vigueur. En conclusion, il a été constaté que le budget annuel joue le rôle de plus en plus déstabilisant par rapport au système financier des EAL. Il serait ainsi nécessaire 
de procéder à l'unification de ces deux documents, notamment du budget annuel et des prévisions financières pluriannuelles avec leur hiérarchie précise.

Mots-clés: budget annuel, prévisions financières pluriannuelles, système financier des EAL, facteurs déstabilisants

\section{Годовой бюджет: Инструмент стабилизации или дестабилизации финансовой системы единиц местного самоуправления?}

Предметом исследования, как и его целью, является ответ на вопрос о том, следует ли по-прежнему считать годовой бюджет основным документом и основой для управления финансами единиц местного самоуправления или нужно внести изменения в бюджетную систему. Сомнения относятся к тому, является ли годовой бюджет в нынешних условиях инструментом стабилизации или дестабилизации финансовой системы местного самоуправления. Принятие в 2009 г. в Законе о государственных финансах системы двух независимых документов, т.е. годового бюджета и долгосрочного финансового прогноза, без определения их иерархии и уточнения их взаимных связей, не способствует финансовой устойчивости единиц местного самоуправления, рассматриваемой с точки зрения исполнения бюджета и последствий, принятых органами местного самоуправления, решений. Настоящие исследование основано на анализе литературы и действующего законодательства. Результаты показывают, что годовой бюджет все чаще играет дестабилизационную роль по отношению к финансовой системе единиц местного самоуправления. Поэтому следует стремиться к интеграции обоих документов, т.е. годового бюджета и долгосрочного финансового прогноза, и к определению их иерархии.

Ключевые слова: годовой бюджет, долгосрочный финансовый прогноз, финансовая система местного самоуправления, инструменты стабилизации 